\title{
Adult T-cell leukemia/lymphoma: report of two cases
}

\author{
Leucemia/linfoma de células T do adulto: relato de dois casos
}

\author{
Ricardo Aparecido Olivo ${ }^{1,2}$, Fabrício Frederico Mendes Martins', \\ Sheila Soares ${ }^{1,2}$ and Helio Moraes-Souza ${ }^{1}{ }^{2}$
}

\begin{abstract}
Adult T-cell leukemia/lymphoma is a lymphoproliferative disorder of mature T lymphocytes associated with infection with human T-cell lymphotrophic virus type I (HTLV-I). Adult T-cell leukemia/lymphoma is characterized by clinical and laboratory polymorphism that allows it to be classified into four distinct subgroups: smoldering, chronic, acute and lymphomatous types. We present here two cases of adult T-cell leukemia/lymphoma, respectively in the acute and lymphomatous forms of the disease. Case 1 was a 35 -year-old woman who presented abdominal distension accompanied by hepatosplenomegaly, adenomegaly, skin lesions, positivity for anti-HTLV-I antibodies and leukocytosis with the presence of flower cells. Case 2 was a 38-year-old man who was admitted with generalized lymphadenomegaly, positivity for anti-HTLV-I antibodies, hypercalcemia and osteolytic lesions. In this paper, we correlate the clinical-laboratory findings of these two cases with data in the literature.
\end{abstract}

Key-words: Human T-cell lymphotrophic virus. Adult T-cell leukemia/lymphoma. Flower cell.

\section{RESUMO}

A leucemia/linfoma de células T do adulto é um distúrbio linfoproliferativo de linfócitos T maduros associado à infecção pelo vírus linfotrópico de células T humanas tipo I (HTLV-I). A leucemia/linfoma de células T do adulto tem polimorfismo clínico e laboratorial, que a classifica em quatro subgrupos distintos entre si: smoldering, crônica, aguda e linfomatosa. Apresentamos neste artigo, dois casos de leucemia/linfoma de células T do adulto, respectivamente, nas formas aguda e linfomatosa da doença. 0 caso 1: uma paciente de 35 anos apresentava distensão abdominal com hepatoesplenomegalia, adenomegalia, lesões cutâneas, anticorpos anti-HTLV-I positivo e leucocitose com presença de flower cell. 0 caso 2: homem de 38 anos, internado com linfadenomegalia generalizada, anticorpos anti-HTLV-I positivo, hipercalcemia e lesões osteolíticas. Neste artigo correlacionamos os achados clínicos e laboratoriais destes dois casos com dados da literatura.

Palavras-chaves: Vírus linfotrópico de células T humanas. Leucemia/linfoma células T do Adulto. Flower cell.

Adult T-cell leukemia/lymphoma (ATLL) is characterized by proliferation of T cells infected with human T-cell leukemia virus type I; an aggressive clinical course accompanied by infiltration of skin, liver, spleen, lymph nodes, gastrointestinal tract, lungs and bone; hypercalcemia; and the presence of leukemic cells with multilobulated nuclei (flower cells) ${ }^{27282930}$. ATLL was described as a clinical entity in $1977^{27}$. The first human retrovirus was isolated from cells of a patient with cutaneous T-cell lymphoma in 1980, and it was called human T-cell leukemia virus type I (HTLV-I) ${ }^{20}$. However, the relationship between ATLL and HTLV-I was only established in 1981, when viral antigens in leukemic cells were detected by indirect immunofluorescence ${ }^{10}$.

HTLV-I is endemic in some regions of the world, such as Japan (southwestern islands), Caribbean islands (Jamaica, Martinique, Haiti), Central Africa and South America. The worldwide distribution of ATLL follows that of HTLV-I ${ }^{21}$. There is evidence indicating that HTLV originated in Africa and was brought to the Caribbean islands through the slave trade and to Japan by the African crews of Portuguese ships in the 16th and 17th centuries. However, there are reports of this retrovirus infection among native Japanese during prehistoric times .

In Brazil, two non-mutually exclusive possibilities exist for the origin of HTLV-I: an African origin (black slave trade ships) and Japanese immigration ${ }^{12} 1221$. However, HTLV-II came to Brazil through Asian migrations about 12,000 years ago and is found in Brazil among indigenous populations in the north of the country?.

The prevalence of HTLV-I/II infection in Brazil ranges from 0.08 to $1.8 \%$, depending on the region and sampling ${ }^{822}$. Here, 2.5 million people are infected with HTLV-I/II, and thus this country presents the largest absolute number of cases worldwide ${ }^{22}$.

\footnotetext{
1. Disciplina de Hematologia e Hemoterapia, Universidade Federal do Triângulo Mineiro, Uberaba, MG. 2. Fundação Hemominas, Uberaba, MG. Address to: Dr. Helio Moraes-Souza. Hemocentro Regional de Uberaba. Av. Dr. Getúlio Guaritá 250, 38025-240 Uberaba, MG.

Tel: 553433125077

e-mail: helio.moraes@hemominas.mg.gov.br

Recebido para publicação em: 03/09/2007

Aceito em: 16/06/2008
} 
According to data from the National Cancer Institute (INCA), Rio de Janeiro and Bahia are the states with the largest numbers of patients diagnosed with ATLL, with 110 and 49 documented cases, respectively, out of the total of 238 cases that were recorded in Brazil between 1992 and 1999, followed by Recife and São Paulo ${ }^{25}$. In a previous study investigating the first 150 cases documented, only seven were reported in Minas Gerais ${ }^{17}$. A recent study has documented 70 cases of ATLL in Bahia ${ }^{4}$.

HTLV-I/II is mainly transmitted by the vertical route, especially during breast-feeding (infected lymphocytes in maternal milk), while transplacental transmission is rare ${ }^{1121}$. Transmission through sexual intercourse, transfusions of blood and blood derivatives and contaminated needles has also been reported. In Brazil, testing of blood donors for HTLV-I/II became obligatory in $1993^{821}$.

HTLV-I promotes the proliferation of infected cells through expression of the Tax gene. In turn, this interacts with cellular factors, to favor synthesis of cytokines and anti-apoptotic genes such as bcl- $x L$, survivin and $c A M P$ response element-binding (CREB) and, consequently, T-cell immortalization and leukemogenesis. The Tax gene also interferes with the functions of $p 53, p 16$ and mitotic arrest deficiency type 1 (MAD1). This interaction allows cells infected with the virus to escape apoptosis, and it also induces genetic instability ${ }^{6}$. The proliferation of infected cells is controlled over various years by cytotoxic T lymphocytes. After a long latency period, ATLL develops in approximately 5\% of asymptomatic subjects infected with HTLV- $\mathrm{I}^{15}$. The clinical spectrum of HTLV-I also includes diseases other than ATLL, such as tropical spastic paraparesis/HTLV-I associated myelopathy, HTLV-I-associated uveitis, and infectious dermatitis ${ }^{21}$.

The diagnostic criteria for ATLL were proposed in 1991, along with its classification into four clinical subtypes. (1) Indolent (smoldering) type: patients are oligosymptomatic and may present skin and pulmonary lesions, while the lymphocyte count is normal. Lactate dehydrogenase levels are less than 1.5 times the upper limit of normal. (2) Chronic type: patients may present lymphadenomegaly and involvement of the liver, spleen, skin and lungs. Absolute lymphocytosis (more than 3,500 cells $/ \mathrm{mm}^{3}$ ) is observed in most cases, and 5\% or more of the lymphocytes are anomalous. Lactate dehydrogenase levels are up to twice the normal limit and calcium levels are normal. (3) Lymphomatous type: this type is characterized by lymphadenomegaly, with or without extranodal lesions. Hypercalcemia may be present. (4) Acute type: this type is the most frequent severe presentation of the disease. These patients are severely ill. Skin manifestations and infiltration of the central nervous system (CNS), bone and bone marrow may be observed, as well as ascites and pleural effusion. The leukocyte count is high, and very atypical lymphoid cells presenting multilobulated or convoluted nuclei (flower cells) are observed. Hypercalcemia is present and lactate dehydrogenase levels are elevated ${ }^{24}$.

In Japan, the mean age at diagnosis of ATLL is 58 years, which can be explained by the long incubation period of HTLV-I (18 to 30 years) until the onset of the disease ${ }^{24}$. However, in Brazil there have been reports of ATLL in children and young adults, with a mean age at diagnosis of 40 years (2-94 years), thus demonstrating a shorter incubation period ${ }^{25}$. In the Caribbean and Africa, patients also present a lower mean age than what was observed in Japan ( 43 years $)^{19}$. With regard to other clinical characteristics, Brazilian patients with ATLL resemble Japanese patients in terms of gender (male/female ratio of 1:1) and the frequency of subtypes of the disease: acute $(60 \%)$, lymphomatous (22\%), chronic (10\%) and indolent $(8 \%)^{25}$. In a recent study in Bahia, the mortality rate was high (87\%). The overall median length of survival was 12 months ${ }^{4}$.

In the present paper, we report two cases of ATLL that were diagnosed at our service at the same time but which presented different clinical manifestations.

\section{CASE REPORT}

Case 1: DRS, a 35-year-old black woman born in São Gotardo (Minas Gerais), was admitted to the teaching hospital of the Federal University of the Triângulo Mineiro (HE/UFTM) with symptoms of myalgia, bone pain, fever, asthenia, weight loss and pruriginous lesions on the scalp that were covered with crusts and were discharging seropurulent secretion. The patient reported a history of pneumonia one month earlier, frequent intestinal parasite infections, especially ascaridiasis, and manifestation of the scalp lesions since childhood accompanied by various secondary infections, including one episode of secondary myiasis. Clinical examination revealed eczematoid and keratotic lesions that presented signs of chronicity, on the external auricle, scalp and adjacent skin (Figure 1). In addition, the patient presented excoriated crusty lesions on the upper and lower limbs compatible with scabies, adenomegaly on both sides of the neck, hepatomegaly, splenomegaly and abdominal distension.

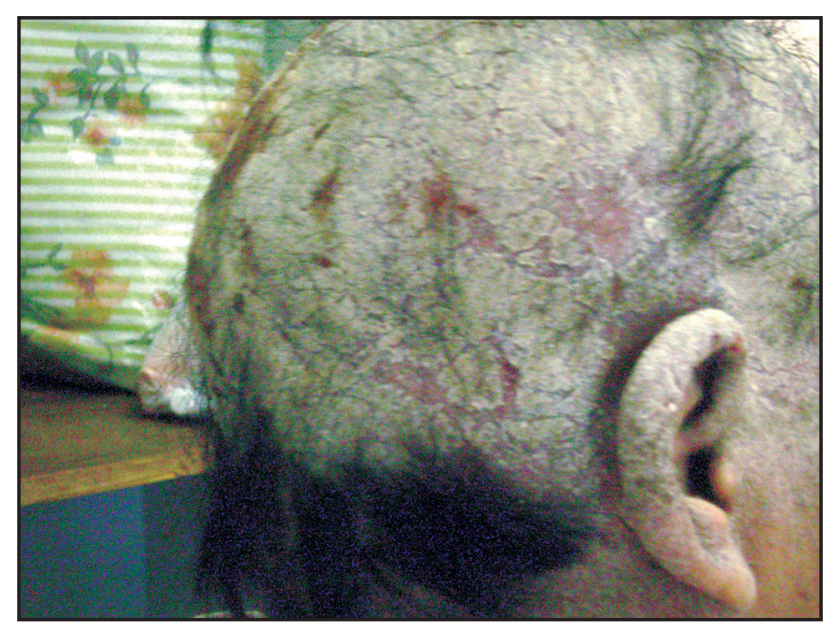

Figure 1 - Infectious dermatitis in scalp and external auricle.

Complementary tests: The hemoglobin concentration was $13.7 \mathrm{~g} / \mathrm{dl}$. The platelet count was $263,000 / \mathrm{mm}^{3}$ and the leukocyte count was $380,000 / \mathrm{mm}^{3}$, including $7 \%$ neutrophils, $1 \%$ eosinophils and $92 \%$ lymphocytes, with $52 \%$ of them presenting evident pleomorphism and some showing characteristics of flower cells (Figure 2). The lactate dehydrogenase concentration was 944 $\mathrm{U} / \mathrm{l}$ and the calcium level was $9.4 \mathrm{mg} / \mathrm{dl}$. Anti-HTLV antibodies were detected by means of ELISA (Ortho-Clinical Diagnostics, Raritan, 


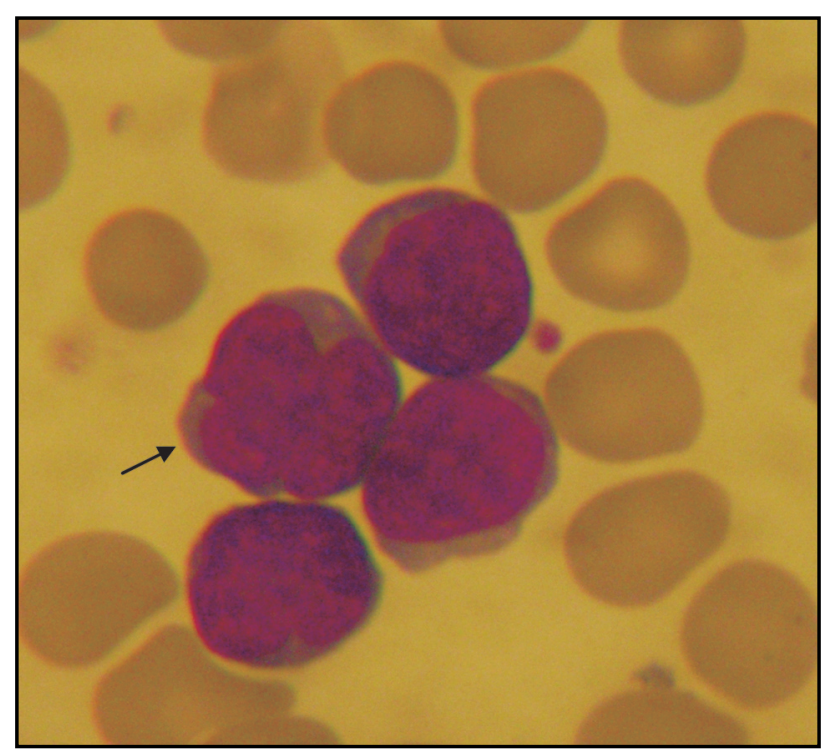

Figure 2 - Flower cell in peripheral blood.

New Jersey, USA) and by Western blot (Genelabs Diagnostics, St. Ingbert, Germany). Immunophenotyping showed 99\% CD2 ${ }^{+}$, $\mathrm{CD}^{+}, \mathrm{CD}^{+}, \mathrm{CD}^{+}, \mathrm{CD}^{-}, \mathrm{CD} 8$, T-cell Receptor alpha/beta ${ }^{+}$, T-cell Receptor gamma/delta, CD16, CD56, CD57 and CD1a T lymphocytes. The bone marrow was hypercellular, with atypical and pleomorphic lymphocytes accounting for $50 \%$ of the cells. Skeletal x-ray presented normal results. Tomography examination showed diffuse bilateral cervical adenomegaly, along with bilaterally enlarged axillae, liver and spleen.

On the basis of the diagnosis of ATLL, induction chemotherapy was started in accordance with the Berlin-Frankfurt-Münster protocol (BFM-5/93). This produced agood hematological response and rapid involution of adenomegaly and hepatosplenomegaly. However, the patient presented signs and symptoms of fungal and viral infections in the upper digestive tract. The latter infection was confirmed by esophageal biopsy, demonstrating the presence of herpes esophagitis, which was responsive to acyclovir. The scalp lesions were treated with a shampoo containing dexamethasone and ketoconazole, but the response was poor.

The patient is alive, with hematological remission fourteen months after the diagnosis.

Case 2. RMM, a 38-year-old black man born in Itabuna (Bahia), was admitted to HE/UFTM with a six-month history of multiple painful nodules in the cervical, axillary and inguinal regions, headache, bone pain, fever and weight loss of $8 \mathrm{~kg}$. The patient also reported progressive irrepressible vomiting, asthenia and hyporexia over the preceding five days. The patient presented a history of previous admissions to this hospital during adolescence because of skin lesions in the cervical region, which, according to the patient's medical files, were erythematous with blisters and crusts. Clinical examination revealed dehydration, weight loss, asthenia, submentonian adenomegaly measuring $1.5 \mathrm{~cm}$ in diameter, bilateral axillary adenomegaly measuring $0.5 \mathrm{~cm}$, and adenomegaly in the bilateral inguinal region measuring 1 to $1.5 \mathrm{~cm}$ in diameter.

Complementary tests: The hemoglobin concentration was $14.0 \mathrm{~g} / \mathrm{dl}$. The leukocyte count was $5,380 / \mathrm{mm}^{3}$ with $70 \%$ neutrophils, 1\% eosinophils, 21\% typical lymphocytes and $8 \%$ monocytes, and the platelet count was $256,000 / \mathrm{mm}^{3}$. Biochemical tests yielded the following results: lactate dehydrogenase, 215U/; beta-2-microglobulin, $5.52 \mathrm{mg} / \mathrm{dl}$; calcium, $14.4 \mathrm{mg} / \mathrm{dl}$; phosphorus, $5.2 \mathrm{mg} / \mathrm{dl}$; uric acid, $11.1 \mathrm{mg} / \mathrm{dl}$; and albumin, 2.9 $\mathrm{g} / \mathrm{dl}$. The presence of anti-HTLV-I antibodies was detected by means of ELISA (Ortho-Clinical Diagnostics, Raritan, New Jersey, USA) and was confirmed by Western blot (Genelabs Diagnostics, St. Ingbert, Germany). Myelogram and bone marrow biopsy showed no evidence of any neoplasm. Skeletal X-ray revealed multiple lytic lesions in the skull (Figure 3) and right femur. Digestive endoscopy showed esophagitis caused by monilia. Abdominal tomography revealed retroperitoneal lymph nodes and a biopsy obtained from the right axillary lymph node was compatible with T-cell lymphoma. Immunohistochemistry identified the presence of $\mathrm{CD}^{+}$lymphocytes.

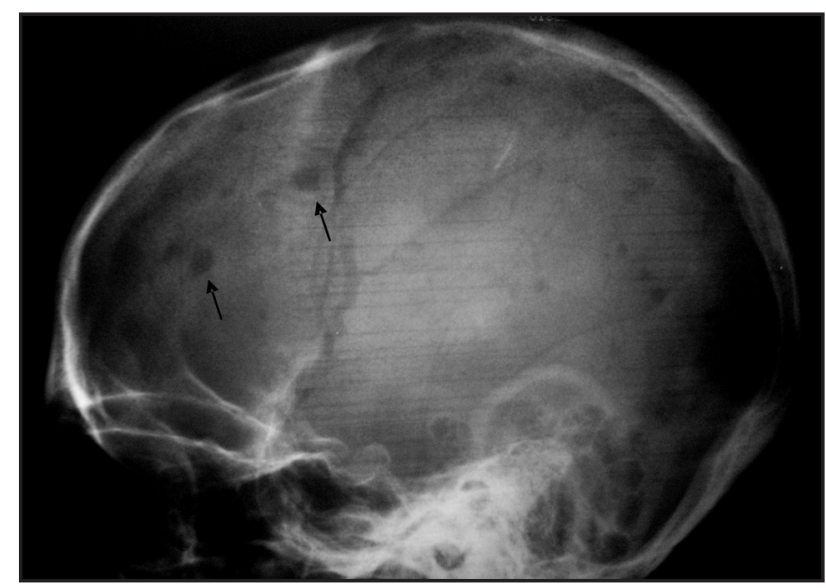

Figure 3: Multiple lytic lesions in the skull.

A rapid clinical response was observed after starting the CHOP protocol (cyclophosphamide, doxorubicin, vincristine and prednisolone), with tumor regression and normalization of serum calcium and phosphorus. However, symptom reactivation and increased serum calcium of up to $19.9 \mathrm{mg} / \mathrm{dl}$ were observed on the twentieth day after chemotherapy. Treatment consisting of hyperhydration with physiological saline, furosemide, zoledronic acid and dexamethasone was started, but was unsuccessful. The patient died of cardiac, respiratory and renal failure and sepsis.

\section{DISCUSSION}

Adult T-cell leukemia/lymphoma was the first human neoplasm to be correlated with a retrovirus, i.e. HTLV-I. The first study on the prevalence of HTLV-I in Brazil was published in 1986, and this reported a positive findings rate of $13 \%$ among Japanese immigrants ${ }^{12}$. The first cases of ATLL in Brazil were described in 1990, in Rio de Janeiro, in a series of 14 patients with lymphadenomegaly, hepatosplenomegaly, hypercalcemia and leukocytosis characterized by atypical lymphocytes with irregular nuclei ${ }^{18}$.

Studies by the National Cancer Institute (INCA) showed that most of the 238 cases of ATLL recorded between 1992 and 1999 
in Brazil occurred in the states of Rio de Janeiro and Bahia ${ }^{25}$. Seven of the first 150 cases of this series were reported in Minas Gerais $^{17}$. In the present study, one patient was from Minas Gerais and the other was born in Bahia but has lived in Minas Gerais since his childhood and is therefore among the first ten cases documented in this state.

Also according to INCA data, the most frequent clinical and laboratory findings of ATLL in Brazil are lymphadenomegaly (83\%), hepatomegaly (60\%), skin lesions (55\%) and hypercalcemia $(56 \%)$. The mean age at diagnosis is 40 years (range 2-94 years). The following subtype frequencies of the disease are observed: acute $(60 \%)$, lymphomatous (22\%), chronic $(10 \%)$ and indolent $(8 \%)^{25}$. Both cases reported in this paper had lymphadenomegaly and were young adults, aged 35 and 38 years, respectively. Case 1 presented significant impairment of general health at diagnosis, as well as bone marrow infiltration, skin lesions, hepatosplenomegaly and marked leukocytosis with the typical flower cell morphology. These findings characterize the acute type of the disease. On the other hand, case 2 is compatible with the lymphomatous type of ATLL, as indicated by the presence of generalized lymphadenomegaly upon histological examination, immunohistochemistry compatible with T-cell lymphoma, elevated calcium levels, osteolytic lesions, positive findings of anti-HTLV antibodies and absence of abnormal lymphocytes (flower cells) in peripheral blood.

Patients with ATLL present marked immunodeficiency resulting from T-cell dysfunction. This favors occurrences of opportunistic infections such as Pneumocystis carinii, Cryptococcus neoformans, Strongyloides stercoralis and cytomegalovirus, among others ${ }^{2829}$. Case 1 already presented disseminated scabies at diagnosis, reported hospitalization due to pneumonia one month earlier and contracted monilia esophagitis followed by herpes esophagitis (confirmed by a biopsy of the esophageal mucosa) during induction chemotherapy.

Hypercalcemia is a frequent complication that is observed in more than $70 \%$ of patients with ATLL, throughout the clinical course of the disease. It causes irrepressible vomiting, intestinal constipation, polyuria, dehydration, acute renal failure, cardiac arrhythmias and changes in consciousness, which were the aggravating factors observed in case 2. ATLL cells express receptor activator of NF- B ligand (RANKL), which induces differentiation of stem cells into osteoclasts, with consequently increased bone resorption. In addition to this mechanism, cytokines (IL-1 , IL-1 ) released by neoplastic cells stimulate parathyroid hormone-related protein, which increases the number of osteoclasts and activates existing ones. The presence of bone pain, hypercalcemia, elevated serum phosphorus and multiple osteolytic lesions in the skull and right femur is compatible with the osteoclast activation observed in case 2 and agrees with reports in the literature ${ }^{613}$.

Lactate dehydrogenase levels are found to be elevated in about $80 \%$ of cases of ATLL, but are not essential for differentiating between leukemia and lymphoma. In this respect, lactate dehydrogenase is more important for differentiating between the smoldering and chronic types, such that increased levels that are more than 1.5 times above normal levels are compatible with the chronic form ${ }^{24}$. Case 1 presented highly elevated lactate dehydrogenase levels, whereas its levels were normal in case 2.

In the 1990s, HTLV-I was associated with severe childhood eczema, known as infectious dermatitis ${ }^{14}$. A pilot study including 14 children with infectious dermatitis and 11 controls with atopic eczema demonstrated that all the children with dermatitis presented anti-HTLV-I antibodies. Since then, several other types of skin lesions have been observed in patients infected with HTLVI, especially those with ATLL. Except for infectious dermatitis, no specific skin lesion is caused by HTLV-I. The underlying mechanism for skin lesions may be direct, i.e. infiltration of the skin with infected lymphocytes, or indirect as a result of immunosuppression ${ }^{1416}$. Case 1 had presented lesions compatible with eczema on the scalp, auricle and face since childhood, which were unresponsive to various treatments and progressed to episodes of recurrent secondary infections, a presentation compatible with infectious dermatitis. In addition to infectious dermatitis, the patient also had diffuse scabies (Sarcoptes scabiei) resulting from the immunodepression caused by the virus. Case 2 also presented previous erythematous lesions with blisters and crusts, during adolescence.

Adult T-cell leukemia/lymphoma is essentially treated by chemotherapy. However, a set of factors including overexpression of the proteins responsible for multiple-drug resistance, mutations or interactions with $p 53$, increased expression of $b c l 2 / b c l 1$, mutations in the Tax gene of HTLV-I, increased thyrodoxin levels and the state of immunodeficiency explain the transitory remissions and short survival which is generally less than 12 months ${ }^{34}$, as observed in case 2 . Case 1 is currently being treated in accordance with to the BFM-5/93 protocol, and is showing improvement in adenomegaly, hepatosplenomegaly and leukocyte count.

Both of these patients presented fungal infection as a complication of ATLL, and herpes in the esophagus was also detected in case 1 . In view of the frequent observation of these complications, treatment protocols for patients with ATLL include prophylaxis against Pneumocystis carinii (cotrimoxazole), fungi (oral antifungal agents) and viruses (oral acyclovir) ${ }^{3}$. This prophylaxis was used in case 1 during the second phase of induction chemotherapy. Infestation with Strongyloides stercoralis is frequent and requires prophylaxis and/or treatment with ivermectin ${ }^{328} 29$, which was also used in these two cases.

Since chemotherapeutic treatment of ATLL is precarious and the complications of the disease are severe, prevention of HTLV-I infection is the only safe alternative. Therefore, since vertical transmission (breast-feeding) is one important route of transmission of HTLV-I, breastfeeding should be discouraged in cases of HTLV-I-positive mothers. Since most infected women who breastfeed are asymptomatic, inclusion of anti-HTLV-I and II screening during the prenatal period should be encouraged throughout the country.

In Belo Horizonte (Minas Gerais), an HTLV prevalence of $0.1 \%$ has been demonstrated among asymptomatic blood donor candidates (ELISA and Western blot). The positivity rate was $25.5 \%$ among relatives and sexual partners of these individuals, thus demonstrating a high prevalence of infection among relatives 
of HTLV-seropositive individuals 5 . Investigation of infection in five relatives of case 1 (four brothers and one daughter) showed prevalence of $20 \%$, with the presence of infection confirmed in one of the four brothers.

In summary, the high prevalence of HTLV-I infection in Brazil, in contrast with the relatively low frequency of ATLL, suggests that the latter may be underdiagnosed. This should be minimized by systematic use of immunophenotyping in all cases with a preliminary diagnosis of lymphoma or leukemia.

\section{REFERENCES}

1. Alcantara LC, Oliveira T, Gordon M, Pybus O, Mascarenhas RE, Seixas MO, Gonçalves M, Hlela C, Cassol S, Galvão-Castro B.Tracing the origin of Brazilian HTLV-1 as determined by analysis of host and viral genes. AIDS 20: 780-782, 2006.

2. Alcantara-Júnior LC, Van Dooren S, Goncalves MS; Kashima, S, Costa MCR, Santos FLN; Bittencourt AL, Dourado I, Filho AA, Covas DT, Vandamme, AM, Galvão-Castro B. Globin haplotypes of human T-cell lymphotropic virus type I-infected individuals in Salvador, Bahia, Brazil, suggest a post-columbian African origin of this virus. Journal of Acquired Immune Deficiency Syndromes 33: 536-542, 2003.

3. Bazarbachi A, Ghez D, Lepelletier Y, Nasr R, de The H, El-Sabban ME, Hermine 0 . New therapeutic approaches for adult T-cell leukemia. The Lancet Oncology 5: 664-672, 2004.

4. Bittencourt AL, Vieira MG, Brites CR, Farre L, Barbosa HS. Adult T-Cell leukemia/ lymphoma in Bahia, Brazil: analysis of prognostic factors in a group of 70 patients. American Journal of Clinical Pathology 128: 875-882, 2007.

5. Catelan-Soares B, Proietti ABFC, Proietti FA. Vírus T linfotrópico humano em familiares de candidatos à doação de sangue soropositivos: disseminação silenciosa. Revista Panamericana de Salud Pública 16: 387-394, 2004.

6. Franchini G. Review: Molecular mechanisms of human T-cell leukemia/ lymphotropic virus type I infection. Blood 86: 3619-3693, 1995.

7. Gallo RC, Sliski A, Wong-Staal F. Origin of human T-cell leukaemia-lymphoma virus. Lancet 8356: 962-963, 1983.

8. Galvão-Castro B, Loures L, Rodriques LG, Sereno A, Ferreira-Junior OC, Franco LG, Muller M, Sampaio DA, Santana A, Passos LM, Proietti F. Distribution of human T-lymphotropic virus type I among blood donors: a nationwide Brazilian study. Transfusion 37: 242-243, 1997.

9. Gotuzzo E, Arango C, Araujo AQC, Isturiz RE. Human T-cell lymphotropic virus-I in Latin America. Infectious Diseases Clinic North America 14: 211-239, 2000.

10. Hinura Y, Nagata K, Hanaoka M, Nakai M, Matsumoto T, Kinoshita K, Shirakawa S, Miyoski I. Adult T-cell leukemia: antigen in an adult T-cell leukemia cell line and detection of antibodies to the antigen in human sera. Proceedings of the National Academy of Sciences of the United States of America 78: 6476-6480, 1981.

11. Kajiyama W, Kashiwagi S, Ikematsu H, Hayashi J, Nomura H, Okochi K. Intrafamilial transmission of adult T cell leukemia vírus. Journal of Infectious Diseases 154: $851-857,1986$

12. Kitagawa T, Fujishita M, Taguchi H, Miyoshi I, Tadokoro H. Antibodies to HTLV-I in Japanese immigrants in Brazil. Journal of the American Medical Association 256: 2342,1986
13. Kiyokawa T, Yamaguchi K, Takeya M, Takahashi K, Watanabe T, Matsumoto T, Lee SY, Takatsuki K. Hypercalcemia and osteoclast proliferation in adult T-cell leukemia. Cancer 59: 1187-1191, 1987.

14. La Grenade L, Fletcher V, Carberry C, Hanchard B, Cranston B, Williams, NP, Chow M, Blattner WA. Infective dermatitis of Jamaican children 1966-1991. West Indian Medical Journal 41: 33, 1992.

15. Matsuoka M. Review: Human T-cell leukemia virus type I (HTLV-I) infection and the onset of adult T-cell Leukemia (ATL). Retrovirology 2: 27, 2005.

16. Nobre V, Guedes ACM, Proietti FA, Stanciolli E, Martins ML, Serufo JC, Antunes CM, Grossi MA, Lambertucci JR. Lesões dermatológicas em pacientes infectados pelo vírus linfotrópico humano de células T do tipo 1 (HTLV-1). Revista da Sociedade Brasileira de Medicina Tropical 38: 43-52, 2005

17. Oliveira MSP, Loureiro P, Bittencourt A, Chiattone C, Borducchi D, Carvalho SMF, Barbosa HS, Rios M, Sill A, Cheghorn F, Blattner W. Geographic Diversity of Adult T cell Leukemia/Lymphoma in Brazil. International Journal of Cancer 83: 291-298, 1998.

18. Oliveira MSP, Matutes E, Famadas LC, Schultz TF, Calabro Ml, Nucci M. Adult T-cell leukaemia/lymphoma in Brazil and its relation to HTLV-I. Lancet 336: 987-990, 1990.

19. Pawson R, Mufti GJ, Pagliuca A. Management of adult T-cell leukaemia/lymphoma. British Journal of Haematology 100: 453-458, 1998.

20. Poiesz BJ, Ruscetti FW, Gazdar AF, Bunn PA, Minna JD, Gallo RC. Detection and isolation of type $\mathrm{C}$ retrovirus particles from fresh and cultured lymphocytes of a patient with cutaneous T-cell lymphoma. Proceedings of the National Academy of Sciences of the United States of America 77: 7415-7419, 1980.

21. Proietti ABFC. Cadernos do Hemominas: HTLV. Belo Horizonte (MG), 2006.

22. Proietti ABFC, Ribas RGJ, Catalan-Soares CCB, Martins ML, Brito-Melo GEA, Martins-Filho OA, Pinheiro SR, Araújo AQC, Galvão-Castro B, Oliveira MSP, Guedes AC, Proietti FA. Infecção e doença pelos vírus linfotrópicos humanos de células T (HTLV-I/II) no Brasil. Revista da Sociedade Brasileira de Medicina Tropical 35: 499-506, 2002.

23. Proietti FA, Carneiro ACF, Catalan-Soares BC, Murphy EI. Global Epidemiology of HTLV-1 infection and associated diseases. Oncogene 24: 6058-6068, 2005.

24. Shimoyama M, members of the Lymphoma Study Group (1984-87). Diagnostic criteria and classification of clinical subtypes of adult T-cell leukaemia/lymphoma. British Journal of Haematology 79: 428-437, 1991.

25. Silva FA, Meis E, Dobbin JA, Oliveira MSP. Leucemia-linfoma de células T do adulto no Brasil: epidemiologia, tratamento e aspectos controversos. Revista Brasileira de Cancerologia 48: 585-595, 2002.

26. Tajima K, Tominaga S. Epidemiology of adult T-cell leukemia/lymphoma in Japan. Current Topics in Microbiology Immunology 115: 53-66, 1985.

27. Takatsuki K, Uchiyama T, Sagawa K, Yodoi J. Adult T cell Leukemia in Japan. In: $16^{\text {th }}$ International Congress of Hematology, Amsterdam p. 73-77, 1977.

28. Takatsuki K, Yamaguchi K, Kawano F, Hattori T, Nishimura H, Tsuda H, Sanada I, Nakada K, Itai Y. Clinical diversity in adult T-cell leukemia-lymphoma. Cancer Research 45: 4644s-4645s, 1985.

29. Takatsuki K, Yamaguchi K, Kawano F, Nishimura H, Seiki M, Yoshida M.. Clinical aspects of adult T-cell leukemia lymphoma. Microbiology and Immunology 115: 89-97, 1985.

30. Uchiyama T, Yodai J, Sagawa K, Takatsuki K, UchinoH. Adult T-Cell Leukemia: clinical and hematologic features of 16 cases. Blood 50: 481-492, 1977. 